\title{
SALTANT PRODUCTION IN THE FUNGUS CHATOMIUM GLOBOSUM BY ULTRA-VIOLET LIGHT, AND ITS RELATION TO ABSORPTION PROCESSES
}

By A. L. MCAULAY and JOAN M. FORD

Physics Department, University of Tasmania, Hobart

Received 27.xii.46

\section{INTRODUCTION}

Ir has been shown that a certain well-marked saltant of the fungus Chatomium globosum, which has been called $\mathrm{K}$, is produced selectively in large numbers by some ultra-violet frequencies and not at all by other frequencies, although in all experiments other saltants are freely produced (McAulay, Plomley and Ford, I945; and Ford, I946b).

The present paper gives an account of the further investigation of the production of this $\mathrm{K}$ saltant at wave lengths near the threshold, and of the way in which the frequency of production of $\mathrm{K}$ and other saltants varies with wave length.

The relationship between the saltant production curve and absorption curves of nucleic acid and proteins is discussed. It is shown that it is difficult to reconcile the results with the conclusions of Knapp and Schreiber (1939) and others, who believe that mutations produced by ultra-violet radiation are the result of a primary absorption by nucleic acid. On the other hand, all the phenomena observed can be explained in terms of protein absorption if this is looked on as the result of more than one excitation in the protein molecule.

\section{EXPERIMENTAL METHOD}

The source of the ultra-violet and visible frequencies was a commercial mercury vapour discharge lamp (McAulay, Plomley and Ford, 1945), and the large aperture monochromator used for most of the experiments has been described by McAulay and Taylor (1939). A Hilger ( $D_{33}$ ) monochromator was used to improve the resolution in the neighbourhood of the threshold for production of the $\mathrm{K}$ saltant. The Hilger monochromator gives a purer spectrum than the other, but one of much lower intensity. Intensity was measured by means of a vacuum thermopile and a low resistance galvanometer. Considerable difficulty was encountered in obtaining absolute values with the large aperture monochromator on account of the rapid divergence of the beam, and no great accuracy is claimed for them. Relative values are considerably better.

For wave lengths greater than $3 \mathbf{I} 32$ A.U. only the large aperture monochromator was used, as the time involved in irradiation was 
about twelve days at 4047 A.U. even with this monochromator. For wave lengths of 2967 A.U. and shorter, experiments have been made with this instrument as well as with the Hilger. Glass filters (see also McAulay, Plomley and Ford, I945; and Ford, I946 (b)) were used to prevent contamination of long wave lengths by short wave lengths. When using the Hilger monochromator the spectral line was isolated by a slit placed immediately in front of the experimental spores, and the controls were placed in the line of the experimental spores, just beyond the limit of the spectral line. In this way they served as a check on any radiation of other wave lengths that might be irregularly reflected from the spectrometer telescope. In experiments on the 4047 line with the large monochromator the controls were situated in the yellow line of the mercury spectrum so that they were subjected to a greater dose of longer wave length radiation than the experimental material.

The filters varied from a fine corex glass coverslip at 2804 A.U. to five microscope slides at $3^{6} 5^{6}$ A.U., and three thicknesses of Crookes glass at 4047 A.U., the visible violet line.

The method of spreading and irradiating the spores and subsequent single spore and dilution plate techniques have been described by McAulay, Plomley and Ford (1945). The fungus used was Chatomium globosum (Ascomycetes, Sphæriales).

Approximately 2000 spores for both experimental and control series were spread on coverslips for each experiment.

Colonies were of single spore origin and each colony was grown in a separate petrie dish. When the colonies were three or four weeks old an analysis was made of the saltants produced. McAulay, Plomley and Ford (1945) describes the classification of saltants, and Ford ( $1946 a$ ) describes the selectively produced saltant " $\mathrm{K}$."

To determine the percentage of the radiation absorbed by the spores at wave lengths 2654 A.U. and 2804 A.U. a photographic method was employed. A layer of spores, one spore thick, was spread behind a pin-hole $0.2 \mathrm{~mm}$. in diameter on a quartz coverslip. With care, an area of this size could be selected with a uniform layer of spores. Positive film was exposed behind this pin hole in close contact with the coverslip. The density of the film behind the spores was matched against film exposed for a suitable time directly to radiation of the same wave length.

\section{RESULTS OF IRRADIATION}

Saltants have been produced by six wave lengths of ultra-violet light, 2654 A.U., 2804 A.U., 2967 A.U., 3 I 32 A.U., 3342 A.U. and 3656 A.U., and by the visible violet line 4047 A.U. Some of the experiments have been described in previous papers, and a full description of the saltants produced has been given (McAulay, Plomley and Ford, I945; and Ford, 1946). The table collects data in which 
one particular parent material was used. This was itself a saltant of Chetomium globosum named Fld. It has characteristics which make it particularly suitable for experimental purposes. Results obtained with other material were consistent with those set out, but this table summarises the most complete and uniform set of experiments.

\section{TABLE}

Saltants produced by monochromatic ultra-violet frequencies 2654 A.U., 2804 A.U., 2967 A.U., 3132 A.U., 3342 A.U. and 3656 A.U., and by the visible violet wave length 4047 A.U. in colonies grown from spores of the fungus Chrtomium globosum $\mathrm{Fld}$, and dose required to produce them. (Experiment roman, control italic)

\begin{tabular}{|c|c|c|c|c|c|c|c|c|}
\hline Wave lengths & $\begin{array}{l}2654 \\
\text { A.U. }\end{array}$ & $\begin{array}{l}2804 \\
\text { A.U. }\end{array}$ & $\begin{array}{l}2967 \\
\text { A.U. }\end{array}$ & $\begin{array}{l}3^{1} 3^{2} \\
\text { A.U. }\end{array}$ & $\begin{array}{l}3342 \\
\text { A.U. }\end{array}$ & $\begin{array}{l}3656 \\
\text { A.U. }\end{array}$ & $\begin{array}{l}4047 \\
\text { A.U. }\end{array}$ & $\begin{array}{c}\text { Total all } \\
\text { wave lengths }\end{array}$ \\
\hline Number of experiments & Io & 8 & 5 & 9 & 9 & 6 & 7 & 54 \\
\hline Number of colonies & 986 & 614 & 644 & 947 & I 272 & 616 & 775 & $5^{854}$ \\
\hline from single spores & $45^{\circ}$ & 284 & 239 & 433 & $5^{87}$ & 303 & 302 & $259^{3}$ \\
\hline Number of $\mathrm{K}$ saltants . & 254 & 170 & 89 & 23 & 18 & I & I & 566 \\
\hline & 0 & $o$ & $o$ & 0 & $o$ & $o$ & $I$ & $t$ \\
\hline Number of other & $8 I$ & 43 & 36 & 44 & 47 & 24 & 26 & $30 \mathrm{r}$ \\
\hline saltants & 3 & 4 & $o$ & 3 & 0 & $I$ & 2 & 1.3 \\
\hline $\begin{array}{l}\text { Percentage of } \mathrm{K} \text { salt- } \\
\text { ants in total number } \\
\text { of colonies grown }\end{array}$ & $\underset{0}{25 \cdot 75}$ & $\begin{array}{c}27 \cdot 7 \\
0\end{array}$ & $\begin{array}{c}13 \cdot 8 \\
0\end{array}$ & $\begin{array}{c}2 \cdot 4 \\
0\end{array}$ & $\begin{array}{c}\mathrm{I} \cdot 3 \\
0\end{array}$ & $\begin{array}{c}0 \cdot 16 \\
0\end{array}$ & $\begin{array}{l}0 \cdot 1 \\
0 \cdot 3\end{array}$ & \\
\hline Percentage of other & $8 \cdot 2$ & $7 \cdot 0$ & $5^{\cdot 6}$ & +6 & $3 \cdot 7$ & $3 \cdot 9$ & $3 \cdot 4$ & $5 \cdot 2$ \\
\hline $\begin{array}{l}\text { saltants in total } \\
\text { number of colonies } \\
\text { grown }\end{array}$ & 0.7 & $I \cdot 4$ & $o$ & 0.7 & 0 & $0 \cdot 3$ & $0 \cdot \hat{\sigma}$ & 0.5 \\
\hline $\begin{array}{l}\text { Ratio of } \mathrm{K} \text { saltants to } \\
\text { others }\end{array}$ & $\begin{array}{r}3 \cdot 1 \\
0\end{array}$ & $\begin{array}{c}3 \cdot 96 \\
o\end{array}$ & $\begin{array}{r}2 \cdot 5 \\
0\end{array}$ & $\begin{array}{c}0.52 \\
0\end{array}$ & 0.35 & $\begin{array}{c}0.042 \\
0\end{array}$ & $\begin{array}{l}.03^{8} \\
.05\end{array}$ & \\
\hline Dose in joules $/ \mathrm{cm}^{2}$ & 0.52 & 0.24 & 0.9 & 30 & I 50 & 900 & 1800 & \\
\hline
\end{tabular}

The table shows the number of experiments performed, the total number of colonies, the number of saltants produced, and the dose for each wave length. A comparison is made with control colonies. All colonies were of single spore origin.

The most striking feature of the ultra-violet experiments is the large number of $\mathrm{K}$ saltants (fig. I) produced by short wave lengths, 2654 A.U., 2804 A.U. and 2967 A.U. More than three times as many K's are produced at these wave lengths as all other saltants put together. Few are produced by 3132 A.U. and 3342 A.U., and practically none by 3656 A.U. and by the visible line 4047 A.U., although under the conditions of high dosage employed the production of other saltants was of the same order as at short wave lengths. It is suggested that the total of three $\mathrm{K}$ saltants found in experiments at 3656 A.U., 4047 A.U., and in control are due to stray ionisation. The $\mathrm{K}$ saltation is an easily recognisable saltant and has been described in detail by Ford (I $946 a$ ).

Saltants other than $\mathrm{K}$ have been classified previously (McAulay, Plomley and Ford, I945) into three main groups, depending on differences from the normal (fig. 2) in growth rates, form, production 
and distribution of perithecia, and mycelial characters. Two saltants are shown in fig. 3. The number of these saltants, other than $\mathrm{K}$, produced by the six frequencies of ultra-violet and the one visible line has been tabulated in the fourth row in the table in this paper. It is possible that in this large group of saltants there are included some which are also produced selectively. The $\mathrm{K}$ saltation has been separated from others in the table on account of its selective production.

In the fifth row of the table the percentages of colonies grown

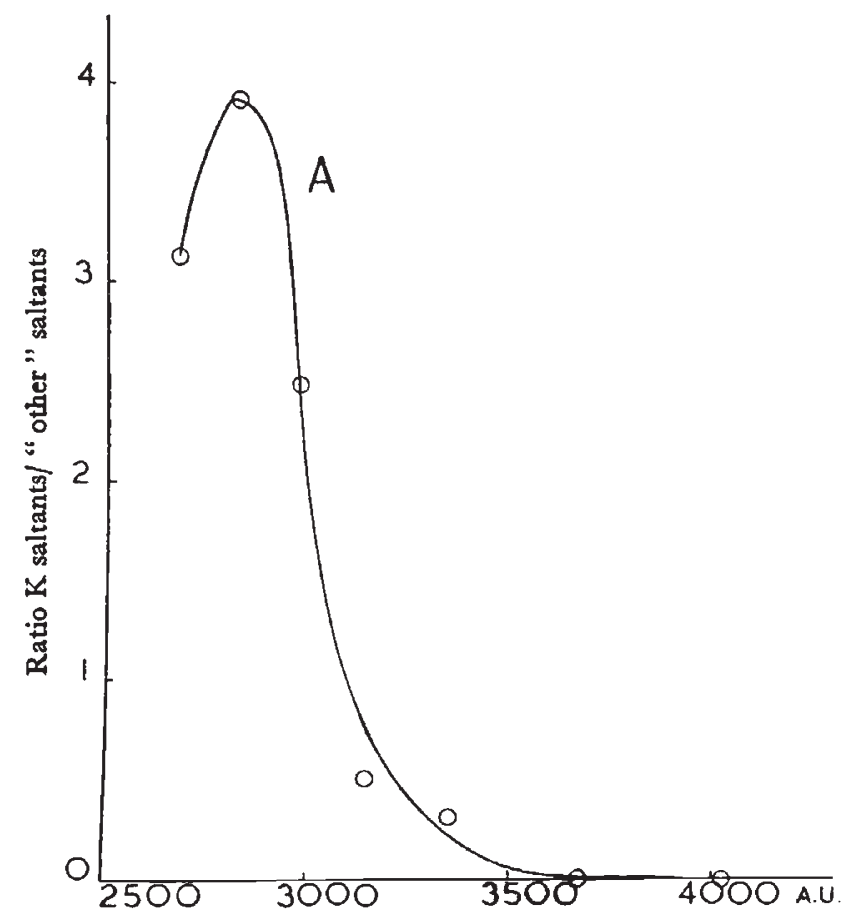

Fig. 4.-Curve A shows the ratio of percentage $\mathrm{K}$ saltants to the percentage " other" saltants (see the table), and curve B shows the optimum doses in joules per sq. cm., for saltant production. Both curves are plotted against wave length. Curve $A$ is natural scale and curve $B$ is plotted on a logarithmic scale. The doses read downwards to bring out the similarity between curves $\mathrm{A}$ and $\mathrm{B}$.

from irradiated spores which became $\mathrm{K}$ saltants are shown for different wave lengths. In the sixth row the same percentages are given for all other saltants grouped together. In row seven the ratio of the $\mathrm{K}$ percentage to the "other" saltant percentage is tabulated and the result is plotted in curve A (fig. 4). These ratios and the graph show most clearly the contrast between the selective production of $\mathrm{K}$ and the production of other saltants.

The last row in the table gives the average doses required at the different wave lengths to produce the effects above described. These doses are plotted in curve B (fig. 4) on a logarithmic scale. The doses read downwards to bring out the similarity between curves $A$ and $B$. 
Two strains of Chatomium globosum, $\mathrm{Kb}$ and $\mathrm{Lj}$ (McAulay, Plomley and Ford, 1945), and another Chetomium globosum saltant, St (McAulay, 1938), have been tested for the production of saltants by ultra-violet frequencies. The resulting saltants have been similar to those found by irradiating $C$. globosum $\mathrm{F} l \mathrm{~d}$ spores, but as $\mathrm{F} l \mathrm{~d}$ was a proved pure strain and convenent for experiment the others were discontinued.

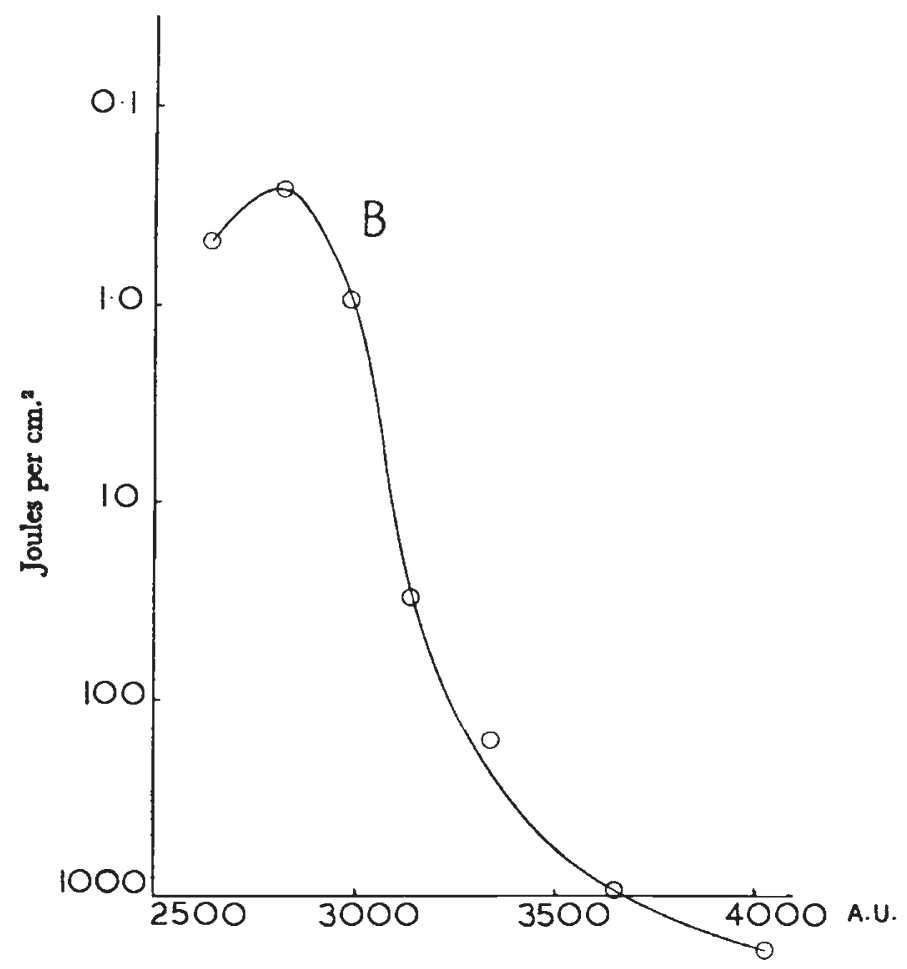

Fic. 4.-Curve B.

A few experiments were made with Chatomium elatum, another species of Chætomium, and the $\mathrm{K}$ saltation and "other" saltants were also produced by short ultra-violet irradiation of the spores.

\section{GENERAL DISCUSSION OF RESULTS}

The results of the present investigation are of interest in the light of the opinion stated by a number of authors (Knapp and Schreiber, I939; MacKenzie and Muller, I940 ; Stadler and Uber, 1942) that mutations produced by ultra-violet light are primarily caused by an absorption process in nucleic acid. Knapp and Schreiber, and Stadler and Uber both experimented with plant material, and the relations they found between mutant production and wave length fit very closely the absorption curve of nucleic acid. A similar fit was found by Emmons and Hollaender (1939) experimenting with a 
fungus. Our results are entirely different, and it would seem that a different explanation should be given for the production of the fungal saltants that we have investigated.

Two quite separate features of our results are inconsistent with the nucleic acid absorption theory. The first is qualitative and indirect. It arises from the clear-cut selective effect that we have recorded, $\mathrm{K}$ saltations being produced by some wave lengths and not by others. Knapp and Schreiber (1939) point out that if nucleic acid absorption is responsible for mutant production it is not to be expected that a selective effect will be found. The second inconsistency between our results and the theory is shown by considering the relationship between doses required for saltant production and wave length, and comparing it with the nucleic acid absorption curve. This matter will now be considered more fully.

Satisfactory measurements have not yet been made of the variation in the number of saltants produced at separate wave lengths with varying doses. The doses given in the table can only be taken as roughly those which correspond to optimum saltant production, and it is not yet known with certainty whether a single or multiple hit mechanism is involved, though the evidence is against single hits. Some conclusions can, however, be drawn from the form of the curve connecting the reciprocal of dose required for optimum saltant production, I/D, with wave length. If saltant production is to be looked on as the result of an absorption in some material, the extinction coefficient for the absorption may be expected to follow in general form the I/D curve. This assumes that the same amount of energy is required for the primary process in saltant production whatever the frequency of the radiation that supplies it.

In fig. 5 , curve $A, I / D$ is plotted against wave length for the range 2654 A.U. to $3^{1} 3^{2}$ A.U. For longer wave lengths $\mathrm{I} / \mathrm{D}$ is too small to be shown on the same scale. The curve relating the extinction coefficient for nucleic acid absorption taken from Caspersson (1936), curve $\mathrm{B}$, is shown for comparison. It is evident that the two curves do not fit. It is only possible to reconcile our results with this absorption as a primary cause of the saltations if very special conditions of screening exist in the spore. There is evidence that this is not the case. The matter will be discussed further below.

Curve $\mathrm{C}$ (fig. 5) shows the absorption curve for a protein, serum albumin, also taken from Caspersson. It is evident that in the spectral region 2654 A.U. to 2967 A.U. saltant production would be very satisfactorily explained by protein absorption of the albumin type.

For wave lengths longer than 2967 A.U. the r/D curve falls more rapidly than the protein absorption curve, and referring to fig. 4, curve $A$, it will be seen that the number of $K$ saltants decreases to zero, but the "other" saltants continue to appear in roughly the same numbers even into the visible spectrum, provided sufficiently large doses are given. 
FIGs. I-3.-Colonies of a single spore origin. Saltants produced by 2654 A.U., a short ultra-violet wave length.

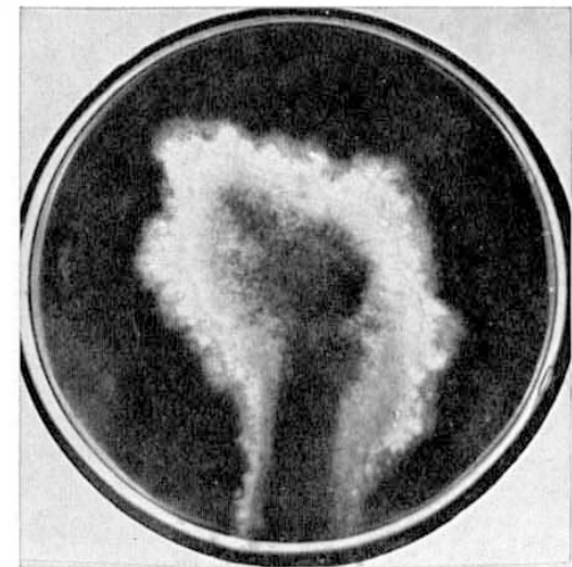

FIG. I $a$.

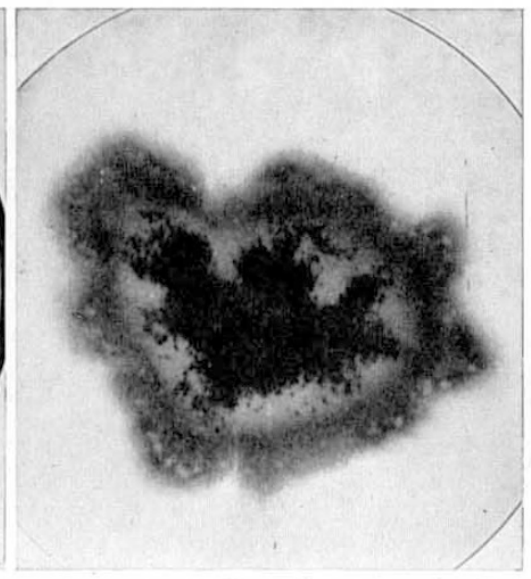

FIG. I $b$.

FIG. 1.-Examples of " $\mathrm{K}$ saltation" colonies. (a) K saltant colony with one normal sector. Reflected light. $\times{ }_{4}^{3}$. (b) Total K saltant colony. Transmitted light. $\times \mathbf{I}$.

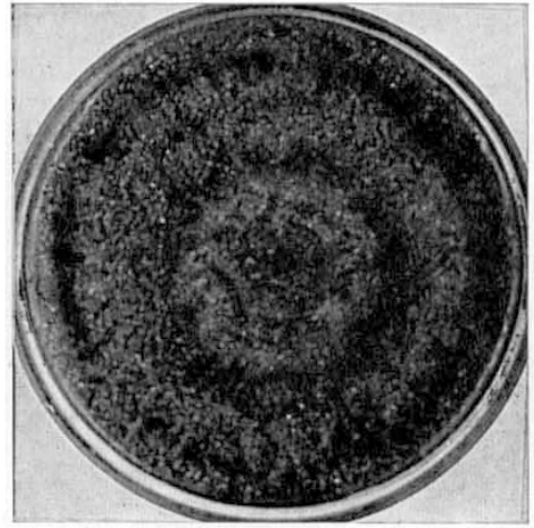

FIG. 2.-Normal colony of Chatominu globusum.Fld. Reflected light. $\times \frac{3}{4}$.

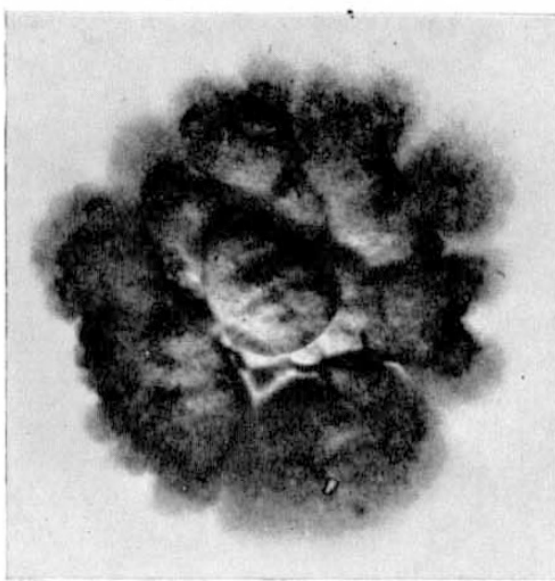

FIG. $3 a$.

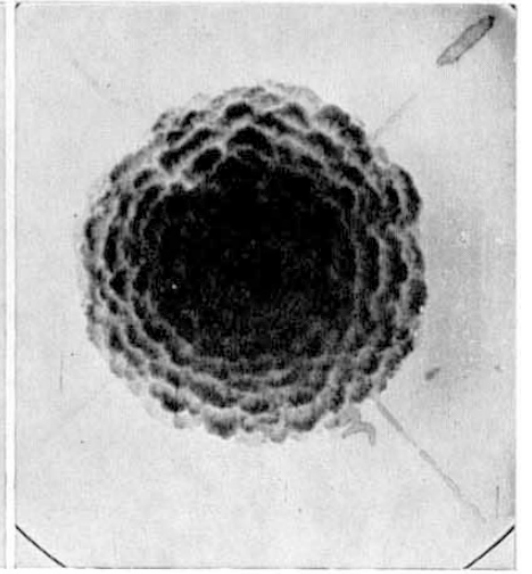

FIG. $3^{b}$.

FIG. 3.-Examples of " other" saltants. (a) Slow growing colony with no perithecia and dense mycelium. Reflected light. $\times \mathrm{I} \frac{1}{4}$. (b) Slow growing saltant with scalloped appearance and few perithecia. Transmitted light. $\times \mathrm{I}$. 


\section{TENTATIVE PROTEIN ABSORPTION THEORY}

The following theory accounts simply for the facts and will be tentatively adopted to give form to the experimental results. The particular change in some protein molecules that gives rise to the strong absorption band with maximum about 2800 A.U. is not excited beyond about 3300 A.U., and this change is the only one that can give rise to " $K$ " saltants. It is also this change which is the most effective stimulus for "other" saltants, but it is not the only one that can produce them. The absorption of longer wave lengths

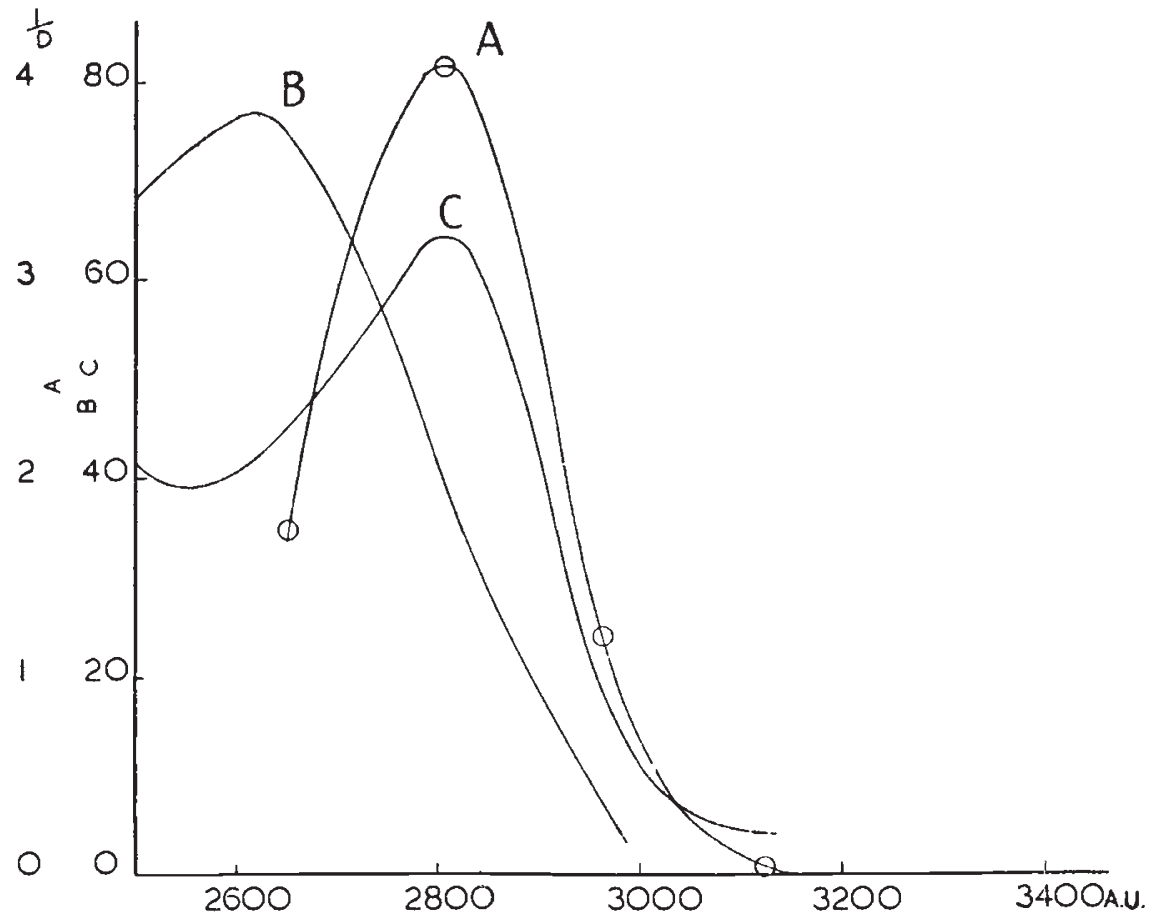

Fig. 5.-Curve A plots the reciprocal of optimum dose for saltant production against wave length. Curve $\mathbf{B}$ shows the extinction coefficient for nucleic acid absorption (after Caspersson, 1936), and curve $\mathrm{C}$ shows the extinction coefficient for a protein, serum albumin (also from Caspersson), plotted against wave length.

can produce saltants other than $K$, but a smaller proportion of the energy absorbed in this spectral region is effective for the purpose. For this reason the saltant dose curve (A, fig. 5), beyond about $3000 \mathrm{~A}$.U. falls more rapidly than the protein absorption curve.

It is recognised that this theory is by no means the only possible one to account for the facts, but its simplicity makes it useful for summarising the results and suggesting further work. 


\section{THE EFFECT OF SCREENING IN CHANGING THE SHAPE OF $A$ I/D, $\lambda$ CURVE FOR SALTANT PRODUCTION}

It is possible, though unlikely, that the form of curve found by us connecting the reciprocal of dose for constant saltant production with wave length (curve A, fig. 5) could be due to a primary absorption in nucleic acid in spite of the difference in shape between it and the nucleic acid extinction coefficient curve. The difference in shape could be due to a screening of the sensitive spot by material with appropriate absorption characteristics, possibly even nucleic acid itself. This is a point of considerable interest as the reverse phenomenon might also be true, and frequency curves found by some authors resembling nucleic acid extinction coefficient curves might be due to absorption in protein with screening by a material that absorbed in the same way. The matter will be discussed from the point of view of our results and it will appear that this cause is very unlikely to account for them.

Curve A, fig. 6, shows the reciprocal of dose for the same saltant production at different wave lengths plotted against wave length. By dose in this curve is meant energy incident on the spore, and the curve is a direct statement of our results. Curve $E$ shows the same curve where dose means the energy that would be received by the sensitive spot if a screen of thickness $10.3 \mu$ absorbing like I I per cent. nucleic acid were interposed between the source of radiation and the sensitive spot. It is derived from curve $\mathrm{A}$ by taking into account absorption in this postulated screen.

It will be seen that with this kind of screening results such as ours might be explained by nucleic acid absorption. The nucleic acid extinction coefficient curve is reproduced (curve B, dotted) for comparison. It is at once evident that screening by nucleic acid itself is unlikely to account for our results as the spore is only $7 \mu$ thick, and according to Caspersson chromosomes in which the acid content is particularly high contain only i I per cent. Our results might still be due to some other screening material with the same type of absorption curve as nucleic acid but with a higher extinction coefficient.

To test this point an attempt was made to obtain the relative absorption by a single layer of spores of radiation of 2654 A.U. and of 2804 A.U. The experiment proved difficult to carry out and the results obtained were subject to large errors. It was possible to establish, however, that the absorption in a single layer of spores was slightly greater for 2654 A.U. than for 2804 A.U., but that the ratio of the absorptions for the full spore thickness was very much less than 2 to 1 . When it is remembered that the sensitive spot must lie within the spore and therefore that the ratio of the screening for 2654 A.U. and 2804 . A.U. must be still smaller it will be seen that the general shape of our curve would not be altered if dose incident on the 
sensitive spot replaced dose incident on the spore. About 99 per cent. of the total radiation incident on the spore is absorbed at these wave lengths.

It is still possible that measurement of absorption in the whole spore does not give a correct picture of the screening, that there might be a local very dense screen with nucleic-acid-like absorption character-

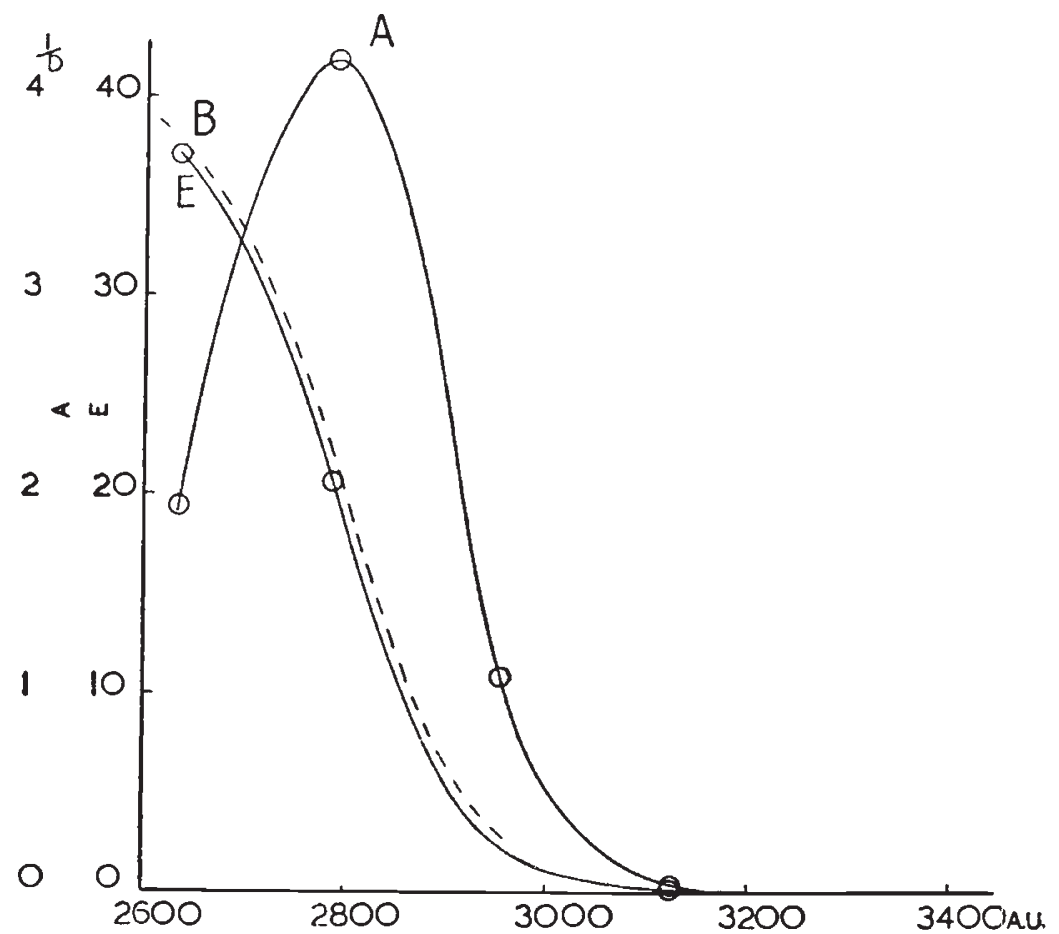

Fig. 6.-Curve A plots reciprocal of the dose incident on the spore (see also fig. 5, curve A) against wave length, and is a direct record of experiment. Curve $\mathrm{E}$ plots reciprocal of the dose reaching the sensitive spot on the assumption that the radiation shown in curve $\mathrm{A}$ is absorbed by a thickness of $10.3 \mu$ II per cent. nucleic acid. Curve $\mathrm{B}$ (dotted) is the nucleic acid extinction coefficient curve (see fig. 5 , curve B).

istics but of much greater opacity, which guards the sensitive spot. Such a theory seems to strain probabilities, and it is a great deal simpler to accept some such explanation as the tentative protein absorption theory proposed. This is particularly true when account is taken of the selective production of $\mathrm{K}$ saltants, which by itself casts serious doubt on a purely nucleic acid absorption theory.

\section{SUMMARY}

Experiments are described on the production of saltants by monochromatic ultra-violet irradiation of spores of the fungus Chatomium globosum. It is found that one saltant which is produced in large numbers by short wave ultra-violet irradiation is not produced by 
long wave lengths. It is also found that the curve connecting the reciprocal of dose for optimum saltant production with wave length is inconsistent with the assumption that mutant production by ultraviolet radiation is due to absorption of the radiation in nucleic acid. This assumption has been found to agree with all results previously reported.

The fact that one saltant is produced selectively suggests strongly that any theory is suspect which requires all mutant production by ultra-violet light to be the result of one absorption process only. A tentative theory of protein absorption is proposed to account for our results.

A brief discussion is given of the effect of screening in altering the shape of the reciprocal dose wave length curve.

\section{REFERENCES}

CASPERSSON, T. $\quad$ I 936 .

Uber den chemischen Aufbau der Strukturen des Zellkernes.

Skand. Arch. Physiol., 73 (supp. 8), 1-151.

EMMONS, C. W., and HOLlaENDER, A. 1939 .

The action of ultra-violet light on dermatophytes. II. Mutations induced in cultures of dermatophytes by exposure of spores to monochromatic ultra-violet radiation.

Amer. 7. Bot., 26, 467-475.

FORD, J. M. I $946 a$.

Morphological, inheritance and growth studies of the $\mathrm{K}$ saltation produced selectively by short wave lengths of ultra-violet irradiation in the fungus Chetomium globosum Kunze (Ascomycetes, Sphæriales).

Aist. 7. Exp. Biol. Med. Sci., 24, 241-250.

FORD, J. M. $1946 b$.

Saltant production by wave lengths of visible and long ultra-violet monochromatic irradiation, and a comparison with saltants produced by short wave lengths of monochromatic ultra-violet irradiation in the fungus Chetomium globosum.

7. Gen. Physiol. (In the press.)

KNAPP, E., and SCHREIBER, H. I939.

Quantitative analyse der mutationauslösenden wirkung monochromatischen u.-v.lichtes in spermatozoiden von Spherocarpus.

Proc. 7th Int. Congr. Genet. 7. Genet. (supp.) (1941), 175-1 76.

M ${ }^{\mathrm{C}}$ AULAY, A. L. 1938.

Production of saltants of Chetomium globosum by monochromatic ultra-violet irradiation.

Proc. Roy. Soc. Tas., I31-139.

M $^{\mathrm{C}}$ AULAY, A. L., PLOMLEY, N. J. B., and FORD, J. M. 1945.

Saltants produced in the fungus Chatomium globosum by monochromatic ultra-violet irradiation and a growth effect characteristic of wave length.

Aust. 7. Exp. Biol. Med. Sci., 23, 53-57. 


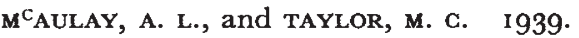

Lethal and quasi-lethal effects produced by monochromatic ultra-violet irradiation. 7. Exp. Biol., I6, 474-482.

MACKENZIE, K., and MULlER, H. J. I940.

Mutation effects of ultra-violet light in Drosophila.

P.R.S., B, I29, 491-516.

STADLER, L. J., and UBER, F. M. 1942.

Genetic effects of ultra-violet radiation in maize. IV. Comparison of monochromatic radiations.

Genetics, 27, 84-1 18. 